\title{
Shape-Controlled Hematite: An Efficient Photoanode for Photoelectrochemical Water Splitting
}

\author{
Mamta Devi Sharma, ${ }^{1}$ Chavi Mahala, ${ }^{1}$ Mrinmoyee Basu ${ }^{1 *}$ \\ ${ }^{1}$ Department of Chemistry, BITS Pilani, Pilani Campus, Rajasthan-333031 \\ mrinmoyee.basu@gmail.com
}

\section{Characterizations:}

Shimadzu Spectrophotometer (model no. UV-2450) with a deuterium and tungstenhalogen lamp was used to study ultra-violate visible spectroscopy. Powder X-ray analysis was carried out using Rigaku Mini Flex II diffractometer with incident radiation of $\mathrm{Cu}-\mathrm{Ka}$. Whole analysis was carried out keeping the scanning rate $2^{\circ}$ per min. Microscope version, XT Platform version, XT UI version, Modal- "APREO S" FE-SEM was used to investigate the morphology of the synthesized $\mathrm{Fe}_{2} \mathrm{O}_{3}$ samples. EDS Analysis was carried out for these samples using the EDS attachment with FESEM which is Aztec (software), X-MaxN, NS: 77887 (Detector) of Oxford company. Raman analysis was carried out using HORIBASCI Raman instrument (model no LabRAM HR EVO). The detector is thermoelectrically cooled charged coupled device (CCD) detector of $576 \times 384$ pixels.

\section{Photoelectrochemical Measurement:}

In this present case, photo electrochemical study was conducted in a threeelectrode system. PEC water splitting was carried out at $1 \mathrm{M} \mathrm{NaOH}$ as the electrolyte. In the cell silver chloride electrode was applied as reference electrode, $\mathrm{Pt}$ wire was used as the counter electrode and sample deposited FTO was used as 
working electrode. Xenon lamp is equipped was used to illuminate the PEC cell with fixed light intensity of $100 \mathrm{~mW} / \mathrm{cm}^{2}$. CH Instrument (CHI604E) was used to record all the electrochemical data at $25{ }^{\circ} \mathrm{C}$. Initially, linear-sweep voltammogram (LSV) was recorded for $\mathrm{Fe}_{2} \mathrm{O}_{3}$ photoanode upon applied potential from $-0.6 \mathrm{~V}$ to $0.6 \mathrm{~V}$ vs. $\mathrm{Ag} / \mathrm{AgCl}$ keeping scan rate $20 \mathrm{mV} / \mathrm{sec}$.

\section{Electrochemical Impedance Study:}

Electrochemical impedance measurement was also performed in a three electrode system. It was performed with the sweeping of frequency from $50 \mathrm{kHZ}$ to $1 \mathrm{~Hz}$. Xenon lamp is equipped with the AM 1.5 filter was used to illuminate the PEC cell with fixed light intensity of $100 \mathrm{~mW} / \mathrm{cm}^{2}$.
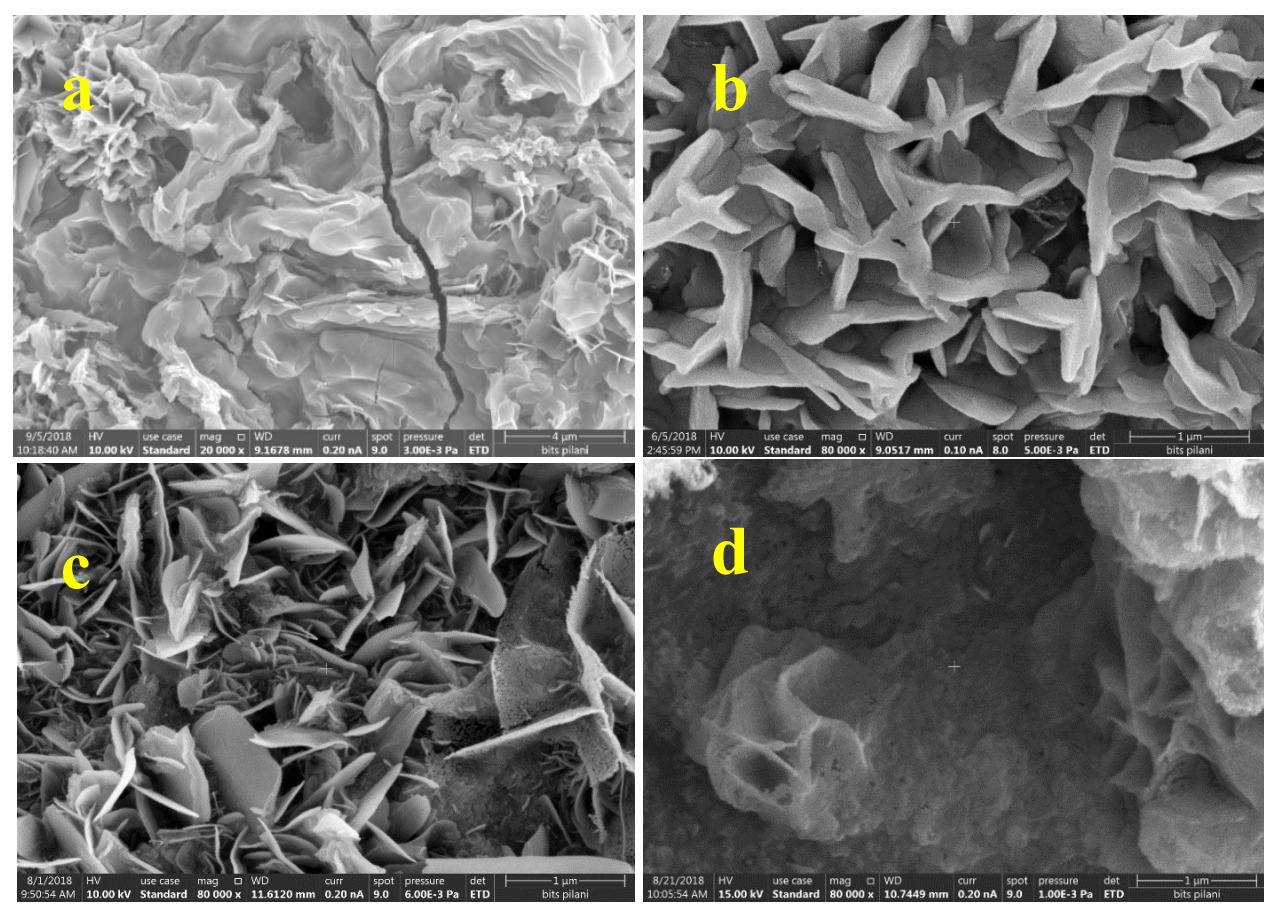
Figure S1: FESEM image of (a) as deposited Fe nanostructure decorated on FTO, $\mathrm{Fe}_{2} \mathrm{O}_{3}$ derived from Fe nanostructure after calcination of (b) 2, (c) 3 and (d) 5 hours respectively.

Thin sheets of $\mathrm{Fe}_{2} \mathrm{O}_{3}$ are obtained after calcination of ' $\mathrm{Fe}$ ' nanostructure at 3 hours at $400{ }^{\circ} \mathrm{C}$. on FTO, it was calcined at various time intervals of 2, 3, 4 and 5 hours and FESEM imaging was done to ascertain the optimum condition of thin sheet synthesis. The $\alpha-\mathrm{Fe}_{2} \mathrm{O}_{3}$ nanosheets were synthesized at $400{ }^{\circ} \mathrm{C}$ for different time intervals like $0,2,3$ and 5 hours; these are shown in Figure S1a-d. The FESEM image of as-deposited 'Fe' nanostructure shows some wrinkles on the top of the FTO. With the increase in calcination time from $0 \mathrm{~h}$ to $2 \mathrm{~h}$, vertically aligned nanosheets of $\alpha-\mathrm{Fe}_{2} \mathrm{O}_{3}$ began to grow with thicker edges. With further increase in the calcination time to 3 hours, nanosheets of $\alpha-\mathrm{Fe}_{2} \mathrm{O}_{3}$ became thinner. Again, increase in calcination time resulted in destruction of the sheet like morphology. Optimum calcination time for the development of $\mathrm{Fe}_{2} \mathrm{O}_{3}$ thin sheet was 3 hours at $400{ }^{\circ} \mathrm{C}$. 


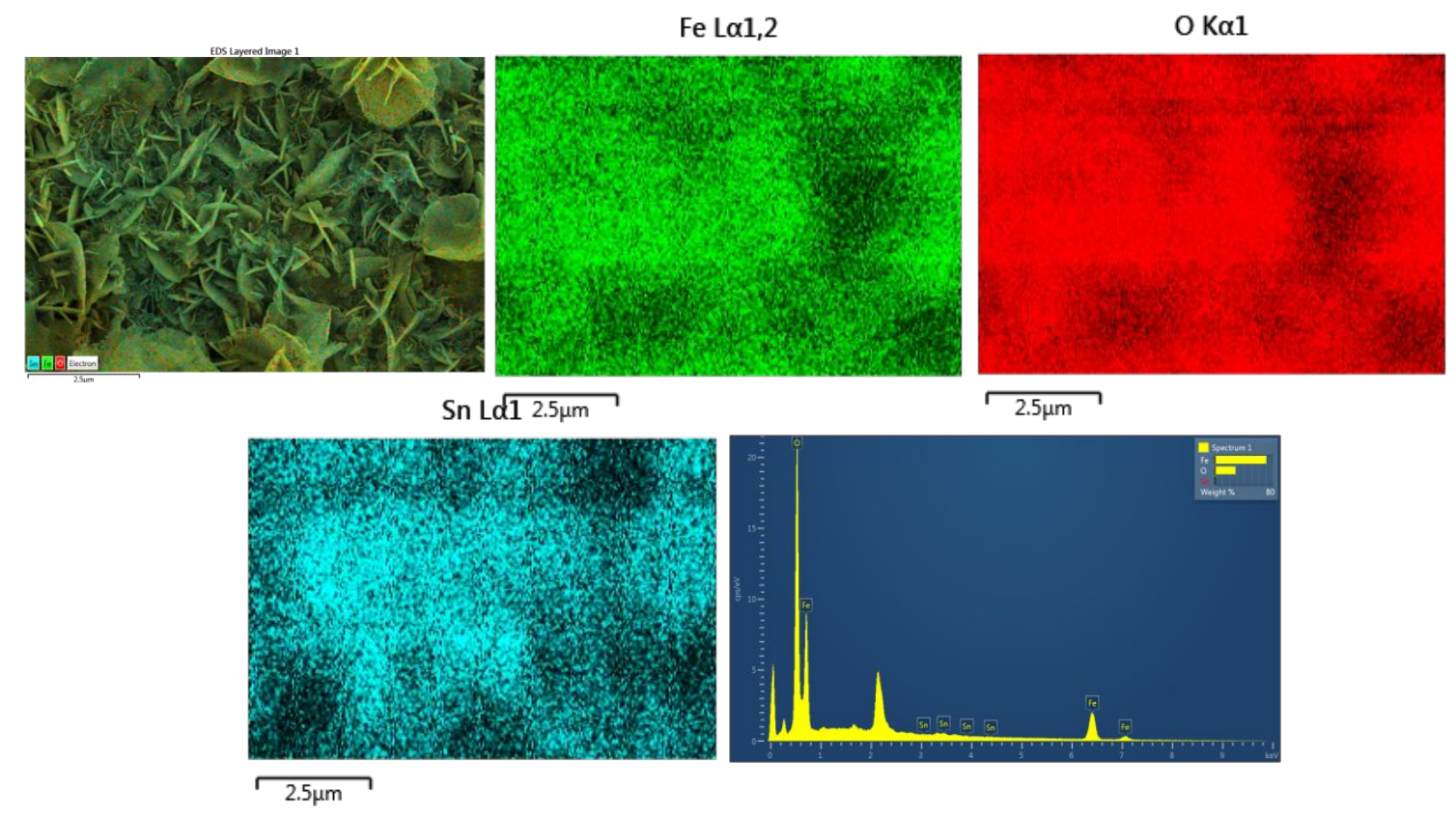

Figure S2: EDS analysis $\mathrm{Fe}_{2} \mathrm{O}_{3}$ nanosheets (Top view) on FTO which shows the uniform distribution of 'Fe', 'O', 'Sn'. 

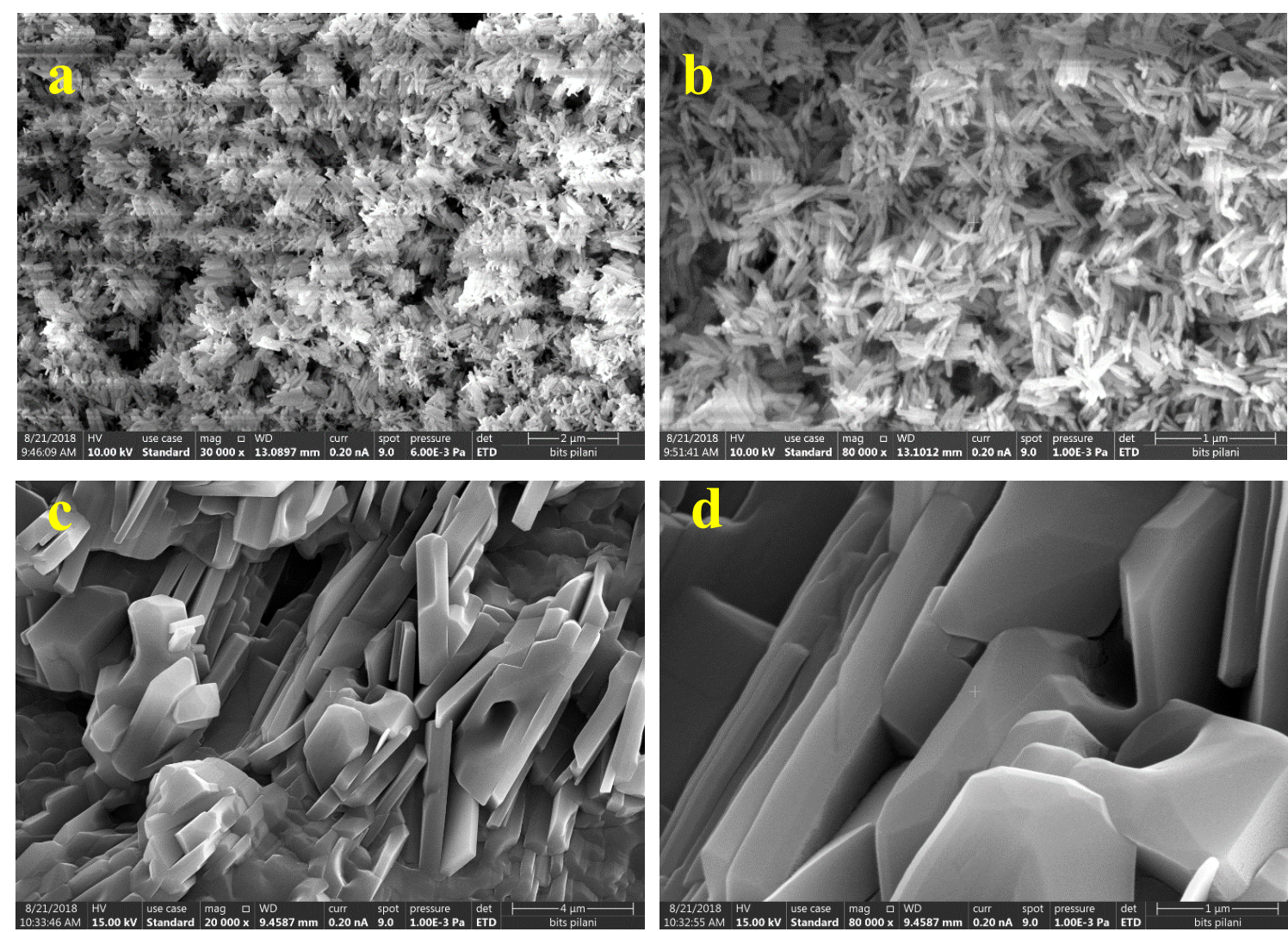

Figure S3: FESEM images at different magnifications (a), (c) Low and (b), (d) High for $\mathrm{Fe}_{2} \mathrm{O}_{3}-\mathrm{NR}$ and $\mathrm{Fe}_{2} \mathrm{O}_{3}-\mathrm{TS}$ respectively. 


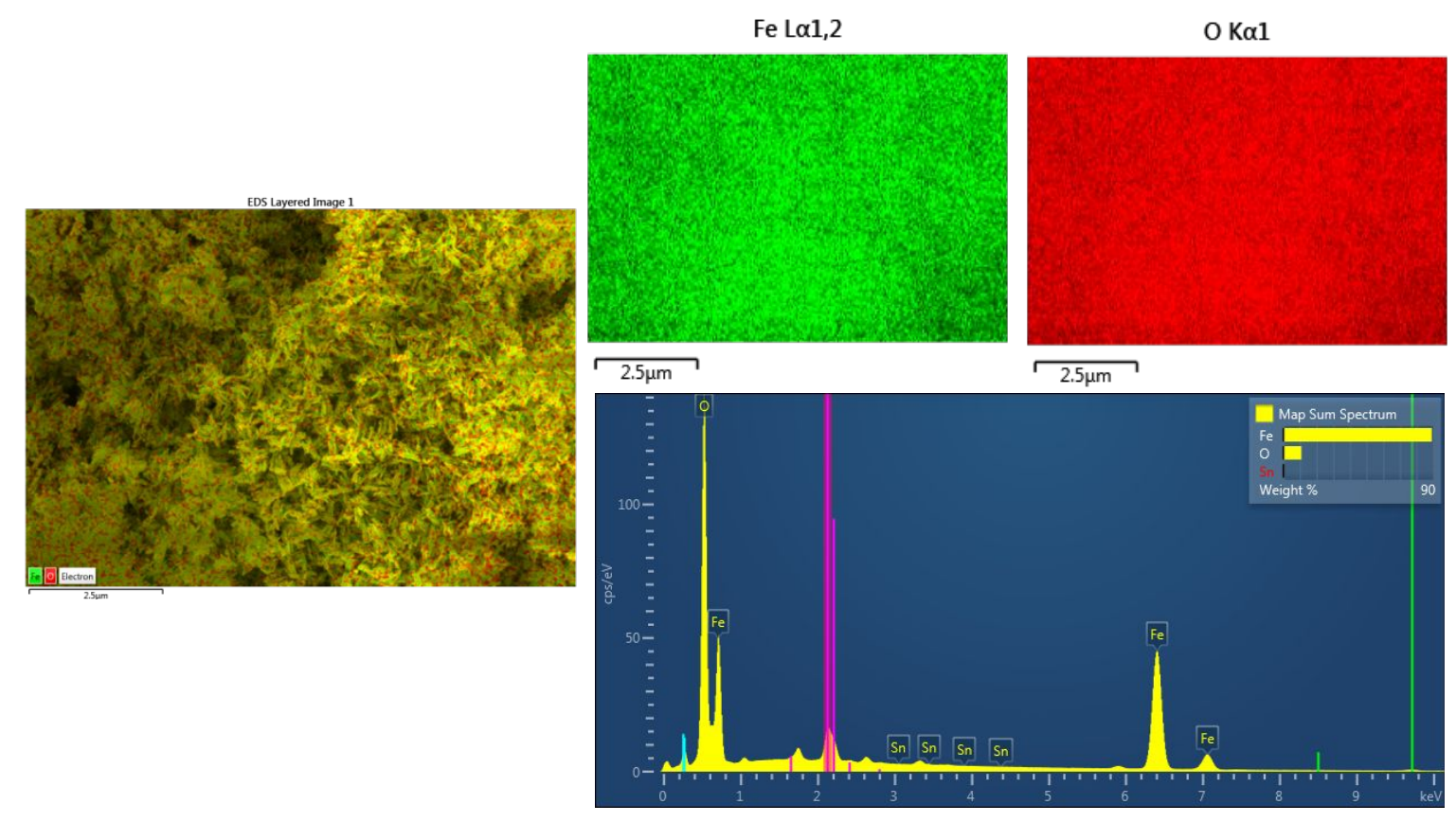

Figure S4: EDS analysis $\mathrm{Fe}_{2} \mathrm{O}_{3}$ nanorods (Top view) on FTO which shows the uniform distribution of 'Fe', 'O' 


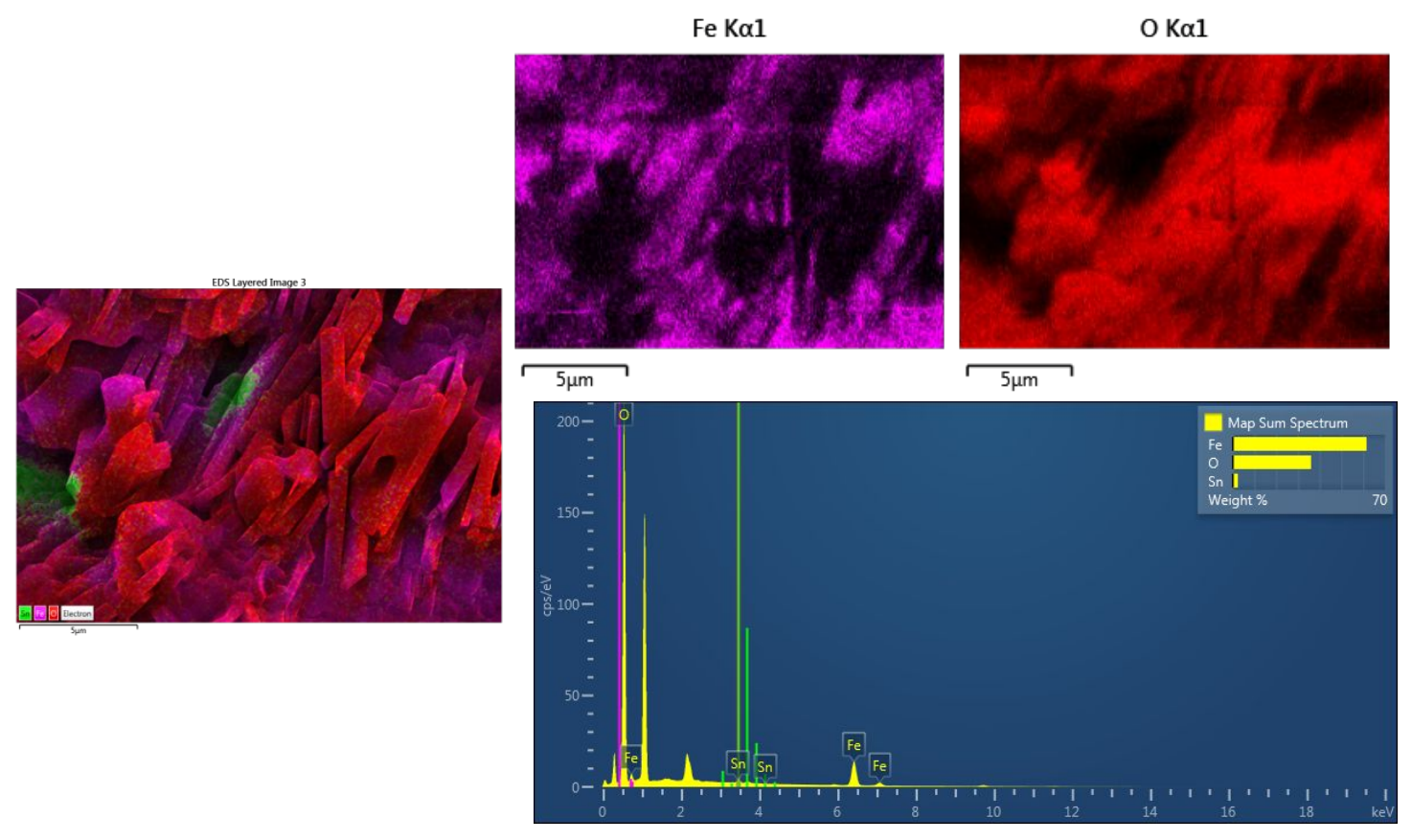

Figure S5: EDS analysis $\mathrm{Fe}_{2} \mathrm{O}_{3}$ thick sheets (Top view) on FTO which shows the uniform distribution of 'Fe', 'O'.
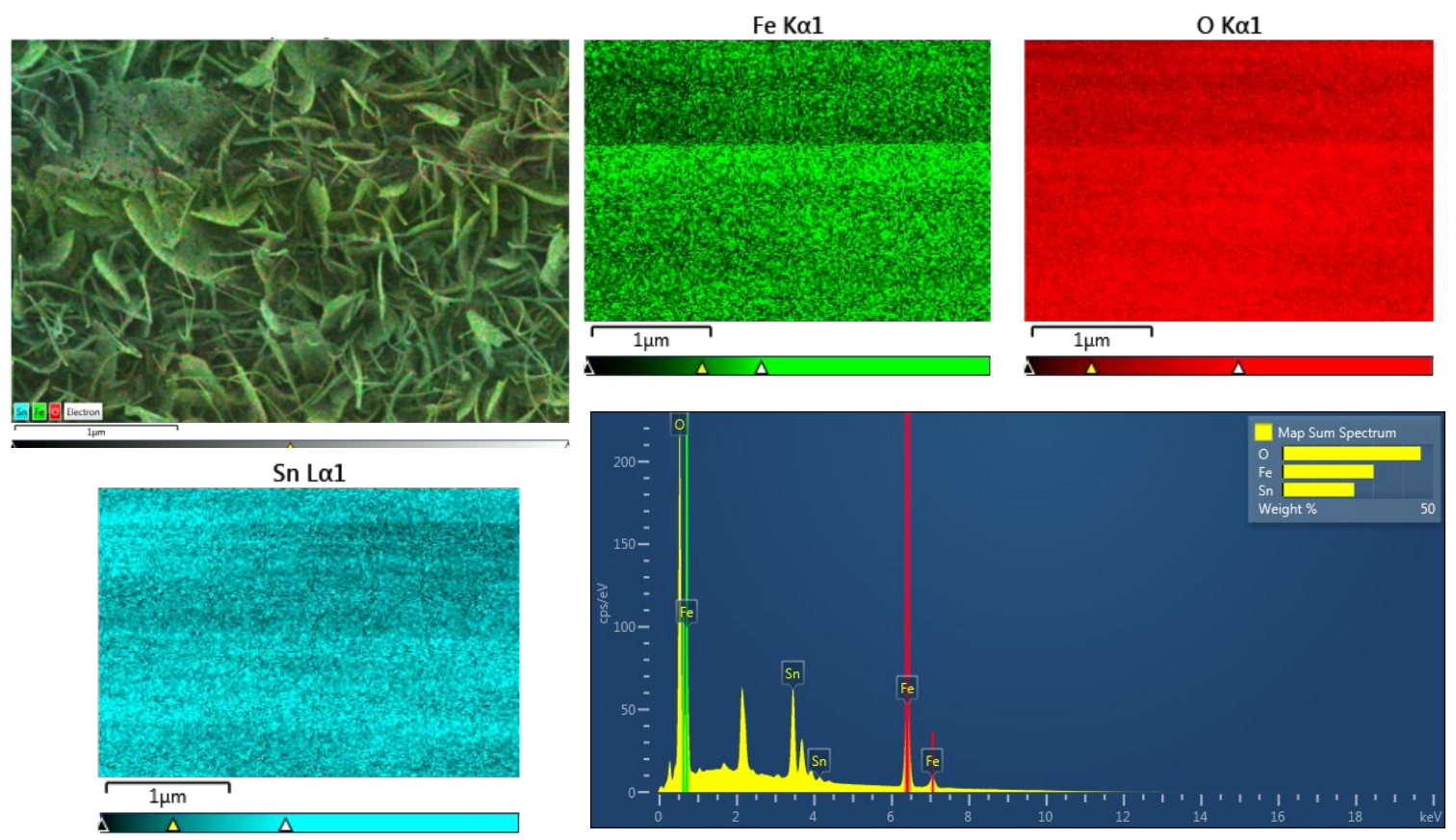

Figure S6: EDS analysis of $\mathrm{Fe}_{2} \mathrm{O}_{3}$-NS after checking stability which shows the presence of 'Fe', 'O' and 'Sn' as elements. 

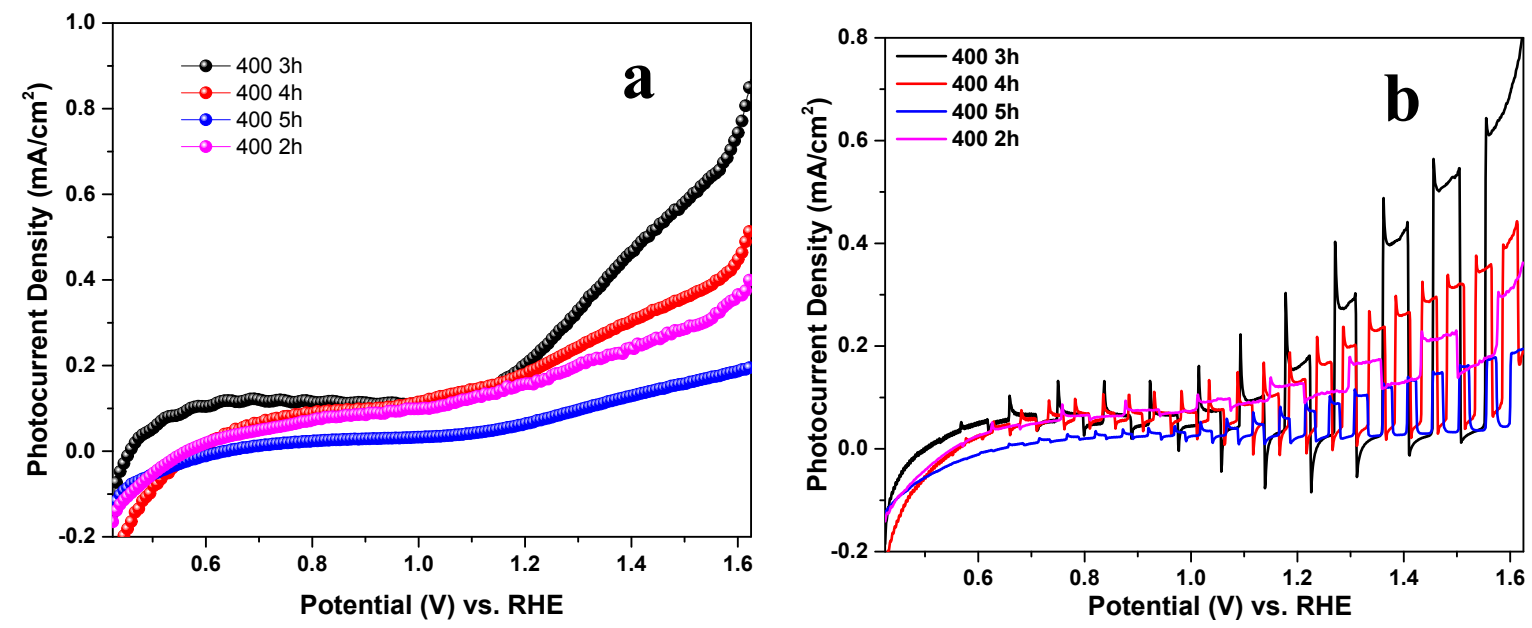

Figure S7: Linear-sweep voltammograms of $\alpha-\mathrm{Fe}_{2} \mathrm{O}_{3}-\mathrm{NS}$ obtained at $400{ }^{\circ} \mathrm{C}$ with different calcinations time ( $2 \mathrm{~h}, 3 \mathrm{~h}, 4 \mathrm{~h}$ and $5 \mathrm{~h})$ (a) continuous illumination (b) chopped illumination condition.

Description: Following electrodeposition technique, at first ' $\mathrm{Fe}$ ' nanosheets were developed on the surface of the FTO, which was verified from XRD and FESEM analysis. Thereafter, these ' $\mathrm{Fe}$ ' nanosheets were calcined at a fixed temperature of $400{ }^{\circ} \mathrm{C}$ for different time intervals like 2, 3, 4 and 5 hours. PEC activities of all these electrodes were checked following LSV technique under continuous illumination and chopped illumination condition (Figure S7a, b). It was observed from the PEC performance that there is a cathodic shift in the onset potential. An increase in the photocurrent density at fixed potential $1.625 \mathrm{~V}$ vs. RHE is observed with calcination time. Optimum condition of calcination was $400{ }^{\circ} \mathrm{C}$ for 3 hours because further increase in calcination time, led to a decrease in PEC activity. Based on the observed FESEM results for all these materials, we may have an explanation of the obtained result of PEC. The FESEM image of as-deposited 'Fe' nanostructure is a thick wrinkle on FTO which suggests the initiation of growth of nanosheets. The FESEM image of $\mathrm{Fe}_{2} \mathrm{O}_{3}$-NS-400-2h showed interconnected thick sheets, which further became thinner upon calcination for $3 \mathrm{~h}$ in the case of $\mathrm{Fe}_{2} \mathrm{O}_{3}-\mathrm{NS}-400-3 \mathrm{~h}$. With the decrease in the thickness of the nanosheets, there was a successive increase in the observed current density at a fixed potential. However, with further increase in calcination time to $5 \mathrm{~h}$, the thin nanosheets structure was completely destroyed and the observed current density was lowered. 
Table S1: Data Comparison for PEC performance of different reports on $\mathrm{Fe}_{2} \mathrm{O}_{3}$ which are closely related to the present work.

\begin{tabular}{|c|c|c|c|c|}
\hline Number & Photoanode & Medium & $\begin{array}{c}\text { Current } \\
\left(\mathrm{mA} / \mathrm{cm}^{2}\right) \text { at } 1.23 \\
\text { V vs. RHE }\end{array}$ & Ref \\
\hline \multirow[t]{2}{*}{1.} & $\alpha-\mathrm{Fe}_{2} \mathrm{O}_{3}$ dendrites & \multirow[t]{2}{*}{$1 \mathrm{M} \mathrm{NaOH}$} & 0.042 & \multirow[t]{2}{*}{32} \\
\hline & $\mathrm{Co}-\mathrm{Pi} / \alpha-\mathrm{Fe}_{2} \mathrm{O}_{3}$ & & 0.066 & \\
\hline \multirow[t]{2}{*}{2.} & $\alpha-\mathrm{Fe}_{2} \mathrm{O}_{3}$ & \multirow[t]{2}{*}{$0.1 \mathrm{M} \mathrm{KOH}$} & 0.53 & \multirow[t]{2}{*}{12} \\
\hline & $\alpha-\mathrm{Fe}_{2} \mathrm{O}_{3} / \mathrm{Ni}-\mathrm{Fe}$ Phosphate & & 1.2 & \\
\hline \multirow[t]{2}{*}{3.} & $\alpha-\mathrm{Fe}_{2} \mathrm{O}_{3}$ & \multirow[t]{2}{*}{$1 \mathrm{M} \mathrm{NaOH}$} & 0.0023 & \multirow[t]{2}{*}{11} \\
\hline & $\mathrm{NiO} @ \alpha-\mathrm{Fe}_{2} \mathrm{O}_{3}$ & & 0.0033 & \\
\hline \multirow[t]{2}{*}{4.} & $\alpha-\mathrm{Fe}_{2} \mathrm{O}_{3}$ & \multirow{2}{*}{$1 \mathrm{M} \mathrm{NaOH}$} & 0.19 & \multirow{2}{*}{39} \\
\hline & $\mathrm{NiO} / \mathrm{Fe}_{2} \mathrm{O}_{3}$ heterojunction & & 4.48 & \\
\hline \multirow[t]{3}{*}{5.} & $\alpha-\mathrm{Fe}_{2} \mathrm{O}_{3}$ & \multirow{3}{*}{$1 \mathrm{M} \mathrm{NaOH}$} & 0.74 & \multirow{3}{*}{33} \\
\hline & $\mathrm{Fe}_{2} \mathrm{O}_{3} / \mathrm{C}_{3} \mathrm{~N}_{4}$ & & 1.15 & \\
\hline & $\mathrm{Fe}_{2} \mathrm{O}_{3} / \mathrm{C}_{3} \mathrm{~N}_{4} / \mathrm{CoOx}$ & & 1.50 & \\
\hline \multirow[t]{2}{*}{6.} & $\mathrm{Fe}_{2} \mathrm{O}_{3}$ & \multirow[t]{2}{*}{$1 \mathrm{M} \mathrm{NaOH}$} & 0.15 & \multirow[t]{2}{*}{21} \\
\hline & $\mathrm{CoPi}-\mathrm{Fe}_{2} \mathrm{O}_{3}$ & & 0.20 & \\
\hline \multirow[t]{2}{*}{7.} & $\alpha-\mathrm{Fe}_{2} \mathrm{O}_{3}$ & \multirow[t]{2}{*}{$0.5 \mathrm{M} \mathrm{NaCl}$} & $\begin{array}{c}0.05 \text { at } 1.0 \mathrm{~V} \text { vs. } \\
\mathrm{Ag} / \mathrm{AgCl}\end{array}$ & \multirow[t]{2}{*}{46} \\
\hline & $\alpha-\mathrm{Fe}_{2} \mathrm{O}_{3} / \mathrm{Ag}_{\mathrm{x}} \mathrm{Fe}_{2-\mathrm{x}} \mathrm{O}_{3}$ & & $\begin{array}{c}0.22 \text { at } 1.0 \mathrm{~V} \text { vs. } \\
\mathrm{Ag} / \mathrm{AgCl}\end{array}$ & \\
\hline \multirow[t]{2}{*}{8.} & $\alpha-\mathrm{Fe}_{2} \mathrm{O}_{3}$ & \multirow[t]{2}{*}{$1 \mathrm{M} \mathrm{NaOH}$} & 0.04 & \multirow[t]{2}{*}{44} \\
\hline & $\mathrm{ZnFe}_{2} \mathrm{O}_{4} / \alpha-\mathrm{Fe}_{2} \mathrm{O}_{3}$ & & 0.30 & \\
\hline 9. & $\mathrm{Fe}_{2} \mathrm{O}_{3}-\mathrm{NS}$ & $1 \mathrm{M} \mathrm{NaOH}$ & 0.235 & $\begin{array}{l}\text { This } \\
\text { work }\end{array}$ \\
\hline
\end{tabular}

